\title{
ANALISIS PERBANDINGAN KINERJA KEUANGAN PERUSAHAAN AKUISITOR SEBELUM DAN SESUDAH MERGER \& AKUISISI (M\&A) TAHUN 2015
}

\author{
Unun Khoirun Nisak \\ Universitas Negeri Surabaya \\ ununnisak16080574126@mhs.unesa.ac.id
}

Abstract

\begin{abstract}
The purpose of this study is to analyze differences in the financial performance of acquisitor companies before and after mergers \& acquisitions (M\&A) in 2015. Financial performance measurement tools are Current Ratio (CR), Debt to Equity Ratio (DER), Return on Equity (ROE), Total Assets Turnover (TATO), and Market Value Added (MVA). The observation period is for 3 years before and after mergers \& acquisitions. The sampling technique that is purposive sampling was obtained by 4 companies of acquisitor. Data analysis techniques used Wilcoxon signed-rank t-test and paired sample t-test. The results of this study are that there is no difference in CR and DER but there are differences in ROE, TATO, MVA in the acquisition company 3 years before and after $M \& A$. The overall results are concluded that the financial performance of the acquisition companies after $M \& A$ decreased so that the synergy expected by the company was not achieved.
\end{abstract}

Keywords: acquisition; financial performance; merger

\section{PENDAHULUAN}

Globalisasi sekarang dengan pertumbuhan ekonomi serta perubahan lingkungan menjadi tuntutan perusahaan untuk bersikap inovatif dalam memutuskan strategi agar dapat bertahan, bersaing dengan kompetitor, bahkan mampu mengembangkan usahanya. Dengan demikian, tidak sedikit perusahaan yang melakukan coorporate action dengan berbagai bentuk untuk menciptakan sebuah strategi yang tepat di mana dapat memberikan keuntungan pada seluruh pihak yang berkepentingan dalam perusahaan (Riyanto, 2001).

Banyak perusahaan sering menggunakan strategi ekspansi. Strategi tersebut terdiri dari ekspansi internal serta eksternal. Investasi ekspansi internal dilakukan dari nol misalnya membangun usaha baru sementara ekspansi eksternal yaitu gabungan aktivitas usaha bersama emiten lainnya misalnya merger \& akuisisi (Sudana, 2011:237).

Sudana (2011:238) mendefinisikan merger adalah gabungan dua perusahan yang memiliki ukuran tidak sama dan hanya salah satu perusahaan yang lebih besar yang akan tetap survive. Sementara akuisisi yaitu penggabungan usaha di mana saham perusahaan target (target company) dikuasai oleh akuisitor (acquiring company) sehingga akuisitor memegang kendali menejemen atas perusahaan yang diakuisisi, namun kedua perusahaan tetap beroperasi sesuai badan hukum masing-masing.

Kppu.go.id (2018) menerangkan seiring dengan perkembangan ekonomi maka Komisi Pengawas Persaingan Usaha (KPPU) mendirikan biro merger guna menangani notifikasi dan penilaian merger maupun akuisisi. Hal tersebut terbukti dengan aktivitas M\&A banyak dilakukan emiten yaitu diketahui jumlah perusahaan merger \& akuisisi di Indonesia tahun 2012 - 2018. Notifikasi merger \& akuisisi dari 2012 hingga tahun 2018 berfluktuatif. Pada tahun 2015 mengalami penurunan sebanyak 51 perusahaan. Fenomena merger dan akuisisi menjadi salah satu parameter kondisi ekonomi suatu negara yaitu informasi dari Badan Pusat Statistik (BPS) pada tahun 2015 pertumbuhan ekonomi di Indonesia juga mengalami penurunan sebesar 4,79\% (bps.go.id, 2015).

Marketeers.com (2015) menginformasikan angka M\&A dalam skala dunia terjadi peningkatan besar. Sepanjang 2015 pada semester kedua M\&A meningkat signifikan namun hal itu tidak terjadi di Indonesia secara keseluruhan. Karena Pemilihan Umum 2014 menyebabkan investasi sempat terhenti hingga situasi membaik. Selain itu, kebijakan dari pemerintah membuat aksi merger dan akuisisi terganggu karena ada kebijakan tentang batas hak milik pihak luar negeri. 
Kompasiana.com (2015) juga menyebutkan bahwa tahun 2015 merupakan tahun pertama adanya Masyarakat Ekonomi ASEAN (MEA) di mana perdagangan bebas dan persaingan antara industri lokal dan industri asing terjadi. Hal tersebut menuntut setiap perusahaan untuk melakukan strategi persaingan pasar dengan aksi merger dan akuisisi. Namun tahun 2015 justru tingkat merger dan akuisisi perusahaan Indonesia rendah, hal ini membuat peneliti tertarik untuk memilih tahun tersebut sebagai tahun penelitian.

Ketercapaian M\&A dinilai oleh tercapainya kinerja keuangan perusahaaan yang lebih baik. Mengukur kinerja keuangan perusahaan dilakukan beberapa metode yang dilihat dari laporan keuangan, salah satunya menggunakan metode rasio keuangan (financial ratio) (Fahmi, 2012:2). Metode rasio keuangan (financial ratio) memiliki keunggulan dan kelemahan. Kelemahan rasio keuangan yaitu resiko yang dihadapi perusahaan kurang diperhatikan karena mengesampingkan cost of equity (Sa'diyah, et al., 2015).

Pada penelitian ini untuk mengatasi kekurangan rasio keuangan dan penyempurnaan penilaian kinerja keuangan, maka ditambah konsep berdasarkan metode Market Value Added (MVA). MVA menjadi proksi terbaik penilaian kinerja keuangan dikembangkan Bennet Stewart dan Joel Staren pendiri Staren Stewart Company (Brigham \& Houston, 2015:111). Dengan demikian, digunakan 4 rasio keuangan dan 1 metode nilai pasar yaitu Liquidity ratio dengan Current Ratio (CR), Leverage ratio dengan Debt to Equity Ratio (DER), Profitability ratio dengan Return on Equity (ROE), Activity ratio dengan Total Asset Turnover (TATO), serta Market Value Added (MVA). Pengamatan dalam penelitian ini menggunakan data selama 3 tahun sebelum dan setelah M\&A selaras oleh Rathih, et al., (2018).

Penelitian dilakukan oleh Laiman \& Hatane ( 2017) dijelaskan tidak ada beda financial performance menggunakan proksi CR perusahaan non-financial selama 3 tahun sebelum \& sesudah merger periode 2007 - 2014. Hasil penelitian oleh Mahesh \& Prasad (2012) pada perusahaan penerbangan di India tahun 2005 - 2010 diketahui bahwa kinerja keuangan dengan rasio DER tidak ada beda 2 tahun sebelum \& sesudah melakukan M\&A.

Penelitian oleh Zen, et al., (2016) tentang kinerja keuangan anak perusahaan (PT ABC) menggunakan proksi ROE menunjukkan hasil terdapat perbedaan 1 dan 4 tahun setelah diakuisisi. Hasil penelitian Tarigan, et al., (2018) dengan rasio TATO menyimpulkan bahwa ada beda setelah M\&A. Hasil Zulvina \& Musdholifah (2010) menggunakan alat ukur MVA menemukan bahwa hasil merger ada beda yang berupa peningkatan pada PT Unilever Indonesia.

Tujuan penelitian ini yaitu menganalisis perbandingan kinerja keuangan perusahaan akuisitor sebelum dan sesudah merger \& akuisisi (M\&A) tahun 2015.

\section{KAJIAN PUSTAKA DAN PENGEMBANGAN HIPOTESIS}

\section{Signaling Theory}

Signaling theory berdasarkan Ross (1977) adalah informasi lengkap tentang perusahaan hanya dimiliki pihak internal untuk disampaikan kepada pihak eksternal khusunya investor supaya ada peningkatan harga saham. Signaling theory dalam bukunya Gumanti (2017:250) merupakan tindakan atau pernyataan dalam penyampaian kinerja dan informasi perusahaan kepada pihak eksternal yaitu pemegang saham. Para pemegang saham cenderung mencari tanda-tanda kinerja, peluang, atau kelemahan perusahaan untuk pertimbangan berinvestasi. Hubungan signaling theory dengan penelitian ini adalah informasi laporan keuangan dianggap sebagai sinyal bagi para pemegang saham untuk melakukan penilaian baik buruknya kinerja perusahaan paska merger dan akusisi sehingga diketahui prospek perusahaan di masa mendatang. 
Unun Khoirun Nisak. Analisis Perbandingan Kinerja Keuangan Perusahaan Akuisitor Sebelum dan Sesudah Merger \& Akuisisi (M\&A) Tahun 2015

\section{Synergy Theory}

Menurut Bradley, et al., (1988) synergy theory yaitu jumlah nilai perusahaan gabungan lebih tinggi daripada jumlah nilai perusahaan individu. Sedangkan P. P. Y. Tarigan \& Pratomo (2015) mengartikan sinergi sebagai hubungan karena perusahaan bergabung bertujuan menciptakan nilai kinerja lebih besar daripada beroperasi sendiri-sendiri. Adanya sinergi bagi pemegang saham apabila mereka mendapat untung yang tidak didapatkan dari diversifikasi portofolio. Hubungan penelitian ini dengan synergy theory adalah setelah dilakukan aksi M\&A dapat tercipta nilai ekonomis dan peningkatan kinerja keuangan daripada berdiri secara terpisah.

\section{Merger}

Merger dalam bukunya Horn \& Wachowicz (2014:364) merupakan gabungan perusahaan di mana pihak dominan saja yang menjalankan kegiatan usaha entitas legal. Perusahaan yang tetap survive pada umumnya yaitu perusahaan yang mempunyai aset dan pangsa pasar lebih besar. Moin (2010:6) mendefinisikan merger yaitu bentuk absorbsi/penyerapan perusahaan satu terhadap perusahaan lainnya. Menurut Ahmed \& Ahmed (2014) merger usaha dibagi menjadi 4 jenis yaitu pertama, horizontal merger yaitu aktivitas menggabungkan diri dengan emiten yang mempunyai kesamaan usaha. Kedua, vertical merger artinya gabungan antar emiten di mana mempunyai keterlibatan dalam berbagai tahap seperti pemasokan bahan. Ketiga, conglomerate merger yaitu penggabungan usaha di mana mempunyai latar belakang berbeda baik jenis perusahaan maupun lini usaha perusahaan. Terakhir, merger konsentris yaitu terjadi apabila dalam penggabungan perusahaan melakukan usaha yang sama tetapi tidak terkait dalam hal kegiatan produksi dan pemasaran.

\section{Akuisisi}

Menurut Hariyani, et al., (2011:22) akuisisi (acquisition/take over) adalah satu perusahaan mengambilalih kontrol modal (saham) pada emiten targetnya. Sementara Moin (2010:6) menjelaskan akuisisi berarti peralihan kendali usaha atas perusahaan acquiree (diambilalih) kepada acquirer (pengambilalih). Jenis akuisisi terdiri dari akuisisi internal yaitu anak perusahaan diambilalih oleh induk di mana mempunyai kesamaan jenis usaha dan akuisisi eksternal yaitu pengambilalihan kepemilikan perusahaan lain dalam jenis usaha yang berbeda (Hariyani, et al., 2011:22).

\section{Kinerja Keuangan}

Kinerja keuangan diartikan kegiatan analisa bertujuan mengetahui perkembangan perusahaan ditinjau dari implementasi peraturan yang ditetapkan dan seluruh data memberikan gambaran dan rekomendasi mengenai kinerja keuangan perusahan (Fahmi, 2012:2).

\section{Analisis Rasio Keuangan}

Analisis rasio keuangan menghubungkan semua unsur laporan keuangan sehingga mampu menginformasikan history usaha serta menilai kondisi usaha di masa sekarang (Kasmir, 2016:196). Menurut Sudana (2011:20) rasio keuangan terbagi menjadi 5 kelompok dasar antara lain liquidity ratio, leverage ratio, profitability ratio, activity ratio, dan market value ratio.

\section{Liquidity Ratio}

Liquidity ratio yaitu menilai kemampuan dalam melunasi seluruh hutangnya jangka pendek (Sudana, 2011:21). Dalam variabel Current Ratio (CR) semakin besar jumlah rasio ini dengan batas tertentu maka semakin baik pula likuiditas perusahaan.

$$
C R=\frac{\text { Current Assets }}{\text { Current Liabilities }} \times 100 \%
$$

\section{Leverage Ratio}

Leverage ratio yaitu menilai jumlah dana perusahaan berasal dari utangnya untuk membiayai seluruh aset di dalam perusahaan (Fahmi, 2012:62). Dalam variabel Debt to Equity Ratio (DER) apabila hasilnya rendah mengindikasikan kecil resiko keuangan perusahaan. 
DER $=\frac{\text { Total Liabilities }}{\text { Equity }} \times 100 \%$

\section{Profitability Ratio}

Profitability ratio yaitu menilai penggunaan seluruh ekuitas dalam menghasilkan keuntungan (Fahmi, 2012:68). Profitabilitas diukur dengan Return on Equity (ROE) di mana semakin besar rasio ini maka semakin efesien pemakaian modal sendiri perusahaan.

ROE $=\frac{\text { Earning After Taxes }}{\text { Total Equity }} \times 100 \%$

\section{Activity Ratio}

Activity ratio menunjukkan pemanfaatan sumber daya dimiliki untuk menunjang kegiatan operasional perusahaan (Fahmi, 2012:65). Variabel Total Assets Turnover (TATO) apabila perputaran semakin besar maka mengindikasikan total asset yang dimiliki perusahaan mampu dimanfaatkan secara efektif untuk meningkatkan penjualan perusahaan.

TATO $=\frac{\text { Sales }}{\text { Total Assets }}$

\section{Market Value Ratio}

Market value ratio yaitu menilai saham emiten di mana sudah diperjualbelikan di bursa (go public) (Sudana, 2011: 23). Dalam variabel Market Value Added (MVA) semakin besar nilai MVA maka semakin baik kinerja menejer perusahaan bagi para pemegang saham (Brigham \& Houston, 2015:68).

$$
\begin{aligned}
\text { MVA } & =\text { Nilai pasar saham }- \text { Modal yang diberikan investor } \\
& =(\text { Saham beredar })(\text { harga saham })-\text { Total ekuitas saham biasa }
\end{aligned}
$$

\section{Hubungan antar Variabel}

Penelitian Tarigan, et al., (2018) menunjukkan secara signifikan variabel CR ada beda setelah M\&A dibandingkan sebelumnya. Rata-rata CR setelah M\&A semakin meningkat karena current assets bentuk piutang meningkat secara signifikan lebih besar daripada jumlah hutang.

H1: Ada perbedaan kinerja keuangan diukur dengan Current Ratio (CR) pada perusahaan akuisitor 3 tahun sebelum dan sesudah merger \& akuisisi.

Hasil penelitian dari Imelda \& Kristianti (2017) pada perusahaan semen periode 2009 - 2013 diketahui bahwa kinerja keuangan dengan variabel DER selama 3 tahun paska aksi M\&A ada bedanya. Karena hutang semakin besar setelah M\&A sehingga nilai DER mengalami peningkatan namun tetap direspon positif oleh pasar karena return saham perusahaan tinggi.

H2: Ada perbedaan kinerja keuangan diukur dengan Debt to Equity Ratio (DER) pada perusahaan akuisitor 3 tahun sebelum dan sesudah merger \& akuisisi.

Eni, et al., (2016) menyimpulkan ROE ada beda 2 dan 3 tahun paska M\&A di mana nilai ROE semakin meningkat karena kecilnya penggunaan modal untuk membiayai strategi ekspansi yang dilakukan perusahaan.

H3: Ada perbedaan kinerja keuangan diukur dengan Return On Equity (ROE) pada perusahaan akuisitor 3 tahun sebelum dan sesudah merger \& akuisisi.

Hasil dari Finansia (2017) menunjukkan secara signifikan variabel TATO ada beda 2 tahun setelah M\&A di BEI periode 2010 - 2013. Hal itu karena semakin besar total aset perusahaan paska M\&A sehingga terjadi perputaran secara optimal yang menyebabkan peningkatan penjualan perusahaan. 
Unun Khoirun Nisak. Analisis Perbandingan Kinerja Keuangan Perusahaan Akuisitor Sebelum dan Sesudah Merger \& Akuisisi (M\&A) Tahun 2015

H4: Ada perbedaan kinerja keuangan diukur dengan Total Asset Turn Over (TATO) pada perusahaan akuisitor 3 tahun sebelum dan sesudah merger \& akuisisi.

Menurut Wardani \& Listiyadi (2018) yaitu adanya perbedaan signifikan nilai MVA 3 tahun paska M\&A emiten listing di BEI periode 2010 - 2012. Karena rata-rata MVA mengalami peningkatan setelah M\&A sehingga diartikan strategi ekspansi berdampak pada peningkatan nilai kekayaan bagi pemegang saham dan hasilnya bernilai positif. Hubungan antar variabel juga digambarkan di Gambar 1.

H5: Ada perbedaan kinerja keuangan diukur dengan Market Value Added (MVA) pada perusahaan akuisitor 3 tahun sebelum dan sesudah merger \& akuisisi.

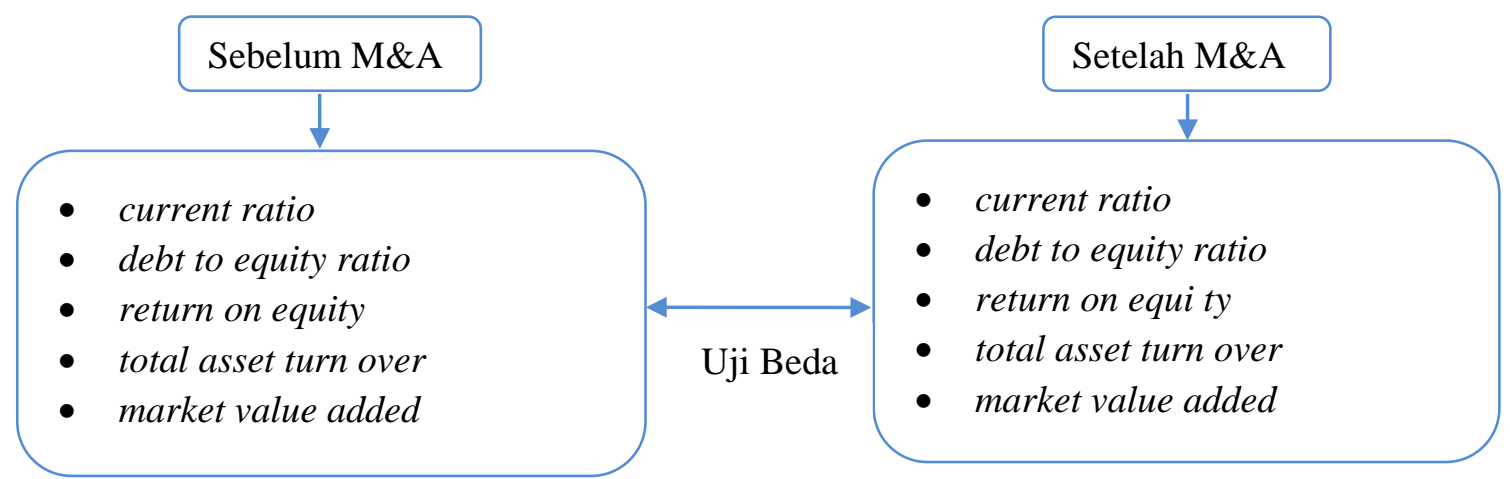

Gambar 1. KERANGKA KONSEPTUAL

\section{METODE PENELITIAN}

Penelitian ini yaitu komparatif dengan jenis data kuatitatif. Data jumlah M\&A berasal dari catatan KPPU melalui www.kppu.go.id. Sedangkan dokumen annual report perusahaan melalui www.idx.co.id dan web milik akuisitor. Teknik pemilihan sampel memakai purposive sampling yaitu akuisitor melakukan satu kali M\&A tahun 2015, akuisitor listing di BEI selain sektor finance, dan annual report akuisitor lengkap periode 2012 - 2018. Diperoleh sampel 4 perusahaan yang terdiri dari PT. First Media (KBLV), PT. Tiphone Mobile Indonesia (TELE), PT. Dian Swastatika Sentosa (DSSA), dan PT. Pembangunan Perumahan (PTPP). Periode pengamatan dilakukan selama 2012 2018 kecuali 2015 sebagai event year. Analisis data meliputi descriptive statistics, uji normalitas Kolmogorov-Smirnov Test, pengujian hipotesis menggunakan uji beda Paired Sample T-test serta Wilcoxon Signed-Rank T-test. Kriteria normalitas saat sig. (2-tailed) > signifikansi $(\alpha)$ sebesar 0,05 yaitu distribusi data normal. Dasar pengambilan keputusan hipotesis yaitu apabila sig. (2-tailed) < tingkat signifikansi $(\alpha)$ 0,05 yaitu terima $\mathrm{Ha}$ dan sig. (2-tailed) > 0,05 yaitu tolak Ha (Sugiyono, 2015:150). Variabel yang digunakan yaitu kinerja keuangan perusahaan akuisitor di mana telah merger \& akuisisi tahun 2015. Rasio keuangan menjadi alat ukur kinerja keuangan berasal dari annual report perusahaan.

\section{HASIL DAN PEMBAHASAN}

\section{Statistik Deskriptif}

Tabel 1 menunjukkan variabel CR sebelum merger \& akuisisi nilai minimal dan maksimal yaitu 76,18 dan 555,55 serta rata-rata 196,2092. Setelah merger \& akuisisi CR diperoleh nilai minimal dan maksimal 5,50 dan 598,91 serta rata-rata 204,6608. Sedangkan variabel DER sebelum merger \& akuisisi diperoleh nilai minimal dan maksimal yaitu 22,65 dan 525,55 dengan mean 173,7042. Setelah merger \& akuisisi DER diperoleh nilai minimal dan maksimal yaitu 73,96 dan 434,80 dengan mean 161,0783 .

Selanjutnya untuk variabel ROE sebelum merger \& akuisisi mempunyai nilai minimal dan maksimal yaitu -0,53 dan 818,18 serta mean 121,0583. Setelah merger \& akuisisi ROE didapatkan nilai minimal 
dan maksimal $-321,03$ dan 14,63 dengan nilai rata-rata sebesar -22,9083. Adapun variabel TATO sebelum merger \& akuisisi diperoleh nilai minimal dan maksimal yaitu 0,31 dan 6,03 serta rata-rata 1,4592. Setelah merger \& akuisisi TATO diperoleh nilai minimal dan maksimal yaitu 0,08 dan 3,52 serta rata-rata 1,0983. Variabel terakhir yaitu MVA sebelum merger \& akuisisi didapatkan nilai minimal dan maksimal -5,E12 dan 1,E13 dengan nilai rata-rata sebesar 1,84E12. Setelah merger \& akuisisi MVA didapatkan nilai terendah dan tertinggi sebesar -1,E13 dan 1,E13 dengan nilai rata-rata sebesar -2,01E12.

Tabel 1.

DESCRIPTIVE STATISTICS

\begin{tabular}{lccccc}
\hline \multicolumn{1}{c}{ Keterangan } & N & Minimum & Maximum & Mean & Std. Deviation \\
\hline CR_3th_Sebelum & 12 & 76,18 & 555,55 & 196,2092 & 133,92048 \\
CR_3th_Setelah & 12 & 5,50 & 598,91 & 204,6608 & 194,03653 \\
DER_3th_Sebelum & 12 & 22,65 & 525,55 & 173,7042 & 192,67417 \\
DER_3th_Setelah & 12 & 73,96 & 434,80 & 161,0783 & 98,44339 \\
ROE_3th_Sebelum & 12 & $-0,53$ & 818,18 & 121,0583 & 250,56273 \\
ROE_3th_Setelah & 12 & $-321,03$ & 14,63 & $-22,9083$ & 94,86483 \\
TATO_3th_Sebelum & 12 & 0,31 & 6,03 & 1,4592 & 1,71515 \\
TATO_3th_Setelah & 12 & 0,08 & 3,52 & 1,0983 & 1,36584 \\
MVA_3th_Sebelum & 12 & $-5, E 12$ & $1, E 13$ & $1,84 \mathrm{E} 12$ & $4,814 \mathrm{E} 12$ \\
MVA_3th_Setelah & 12 & $-1, E 13$ & 1,E13 & $-2,01 \mathrm{E} 12$ & $7,449 \mathrm{E} 12$ \\
\hline
\end{tabular}

Sumber: Output SPSS (data diolah)

\section{Hasil Uji Normalitas}

Tabel 2.

ONE-SAMPLE KOLMOGOROV-SMIRNOV TEST

\begin{tabular}{lcccccc}
\hline \multicolumn{2}{c}{ Keterangan } & CR & DER & ROE & TATO & MVA \\
\hline $\mathrm{N}$ & & 24 & 24 & 24 & 24 & 24 \\
Normal & Mean & 200,4350 & 167,3913 & 49,0750 & 1,2788 & $-8,27 \mathrm{E} 10$ \\
Parameters & $\quad$ Std. & 163,10335 & 149,77015 & 199,34126 & 1,52745 & $6,441 \mathrm{E} 12$ \\
\multicolumn{2}{l}{$\begin{array}{l}\text { Kolmogorov } \\
\text { Kolmiation }\end{array}$} & & & & & \\
Asymp. Sirnov Z & 1,358 & 1,165 & 2,099 & 1,655 & 0,868 \\
\multicolumn{2}{l}{ (2 - tailed) } & 0,050 & 0,132 & 0,000 & 0,008 & 0,438 \\
\hline
\end{tabular}

Sumber: Output SPSS (data diolah)

Tabel 2 diketahui variabel CR, ROE, dan TATO tidak berdistribusi normal karena nilai Asymp. Sig. $\leq 0,05$ maka uji hipotesis memakai Paired Sample T-test. Sedangkan variabel DER dan MVA menunjukkan distribusi data normal dibuktikan Asymp. Sig. >0,05 maka uji hipotesis memakai Wilcoxon Signed-Rank T - test.

\section{Hasil Uji Hipotesis}

Tabel 3 menunjukkan kinerja keuangan diukur dengan CR dan DER tidak ada beda 3 tahun sebelum dan setelah M\&A sehingga hipotesis yang diajukan yaitu H1 dan H2 ditolak. Sedangkan ROE, TATO, dan MVA ada perbedaan 3 tahun sebelum dan setelah M\&A sehingga pengajuan hipotesis yaitu $\mathrm{H} 3, \mathrm{H} 4$, dan $\mathrm{H} 5$ diterima.

Perbedaan Kinerja Keuangan Diukur dengan Current Ratio (CR) pada Perusahaan Akuisitor Sebelum dan Sesudah Merger \& Akuisisi (M\&A)

Hasil yang telah diperoleh dari pengukuran Current Ratio (CR) menunjukkan bahwa H1 ditolak yaitu tidak ada perbedaan kinerja keuangan diukur dengan Current Ratio (CR) pada perusahaan akuisitor 3 
Unun Khoirun Nisak. Analisis Perbandingan Kinerja Keuangan Perusahaan Akuisitor Sebelum dan Sesudah Merger \& Akuisisi (M\&A) Tahun 2015

tahun sebelum dan sesudah merger \& akuisisi. Hal tersebut diperkuat oleh hasil CR yang juga tidak ada beda kinerja keuangan selama 1 tahun dan 2 tahun setelah M\&A. Persebaran data current assets dan current liabilities relatif konstan di mana tidak ada kenaikan atau penurunan secara signifikan.

Tabel 3.

PAIRED SAMPLE T-TEST DAN WILCOXON SIGNED-RANK T-TEST

\begin{tabular}{clccc}
\hline Uji Hipotesis & \multicolumn{1}{c}{ Periode } & $\mathrm{t}$ & Sig. (2 - tailed) & Keterangan \\
\hline Wilcoxon & CR_1th_Sbm - CR_1th_Sdh & $-0,365$ & 0,715 & \\
Signed-Rank $T$ & CR_2th_Sbm - CR_2th_Sdh & $-0,140$ & 0,889 & Tolak H1 \\
- test & CR_3th_Sbm - CR_3th_Sdh & $-0,706$ & 0,48 & \\
\hline \multirow{2}{*}{ Paired Sample } & DER_1th_Sbm - DER_1th_Sdh & 0,58 & 0,602 & \\
T -test & DER_2th_Sbm - DER_2th_Sdh & 1,064 & 0,323 & Tolak H2 \\
& DER_3th_Sbm - DER_3th_Sdh & 0,229 & 0,823 & \\
\hline \multirow{2}{*}{ Wilcoxon } & ROE_1th_Sbm - ROE_1th_Sdh & $-0,730$ & 0,465 & \\
Signed-RankT $T$ & ROE_2th_Sbm - ROE_2th_Sdh & $-1,540$ & 0,123 & Terima H3 \\
- test & ROE_3th_Sbm - ROE_3th_Sdh & $-2,040$ & 0,041 & \\
\hline \multirow{2}{*}{ Wilcoxon } & TATO_1th_Sbm - TATO_1th_Sdh & $-0,730$ & 0,465 & \\
Signed-Rank T & TATO_2th_Sbm - TATO_2th_Sdh & $-1,260$ & 0,208 & Terima H4 \\
- test & TATO_3th_Sbm - TATO_3th_Sdh & $-2,045$ & 0,041 & \\
\hline \multirow{2}{*}{ Paired Sample } & MVA_1th_Sbm - MVA_1th_Sdh & 1,395 & 0,257 & \\
T -test & MVA_2th_Sbm - MVA_2th_Sdh & 2,08 & 0,076 & Terima H5 \\
& MVA_3th_Sbm - MVA_3th_Sdh & 2,507 & 0,029 & \\
\hline
\end{tabular}

Sumber: Output SPSS (data diolah)

Hal tersebut diketahui berubahnya CR antara sebelum dan setelah M\&A dalam penelitian ini yang relatif kecil. Dibuktikan pada Tabel 1. Descriptive statistics bahwa selama periode 3 tahun setelah M\&A nilai rata-rata current ratio hanya meningkat sebesar 4,31\% yaitu 196,20 menjadi 204,66. Perubahan yang relatif kecil tersebut diartikan bahwa aset lancar bertambah paska M\&A yang diiringi pula bertambahnya utang lancar perusahaan. Dengan demikian, tidak ada perbedaan current ratio karena penggunaan aset lancarnya untuk memenuhi utang jangka pendek tidak berubah secara signifikan dari sebelumnya.

Sampel akuisitor mempunyai nilai rasio terendah dialami oleh perusahaan KBLV pada tahun 2018 sebesar 5,50\%. Di mana semakin rendah nilai CR berarti makin rendah juga kemampuan bayar utang perusahaan yang segera jatuh tempo. Sehingga tidak memberikan sinyal bagi investor dalam keputusan investasi dan juga tidak menciptakan sinergi yang lebih baik bagi akuisitor untuk memenuhi utang lancarnya. Dengan demikian, kinerja keuangan proksi CR tidak mendukung teori sinyal dan teori sinergi. Implikasi teori sinyal dan teori sinergi pada penelitian ini untuk meningkatkan kinerja keuangan dengan current ratio sebaiknya pertambahan aset lancar perusahaan semakin lebih besar setelah M\&A untuk membayar utang lancar.

Hasil ini didukung Hasanah \& Oktaviani (2017) yaitu secara signifikan tidak ada bedanya setelah aksi akuisisi dibandingkan sebelumnya, artinya aksi akuisisi tersebut tidak menyebabkan perubahan yang begitu tampak sehingga sinergi yang diharapkan belum bisa tercapai. Hasil ini tidak didukung oleh Tarigan, et al., (2018) menunjukkan bahwa secara signifikan CR ada bedanya sesudah M\&A periode 2009 - 2012. Telah terbukti mean CR sesudah M\&A semakin meningkat karena aset lancar meningkat secara signifikan lebih besar dibandingkan jumlah utang. 


\section{Perbedaan Kinerja Keuangan Diukur dengan Debt to Equity Ratio (DER) pada Perusahaan Akuisitor Sebelum dan Sesudah Merger \& Akuisisi (M\&A)}

Variabel Debt to Equity Ratio (DER) memberikan hasil H2 ditolak yaitu tidak ada perbedaan kinerja keuangan diukur dengan Debt to Equity Ratio (DER) pada perusahaan akuisitor 3 tahun sebelum dan sesudah merger \& akuisisi. Ditunjukan dari tabel 1. Descriptive statistics bahwa lebih besar nilai mean rasio DER sebelum M\&A dibandingkan nilai mean sesudah M\&A yang berarti terjadi penurunan. Hal tersebut juga didukung oleh hasil uji hipotesis yaitu selama 1 dan 2 tahun keduanya tidak memberikan perbedaan paska M\&A. Hal itu mengindikasikan bahwa modal dan utang perusahaan yang telah digabungkan sama-sama meningkat sehingga jumlah utang yang dimiliki perusahaan untuk membiayai kepentingan perusahaan relatif konstan.

Aksi M\&A tidak memberikan hasil banding total liabilities serta equity perusahaan paska M\&A berubah signifikan. Hal itu terlihat dari berubahnya mean DER periode 3 tahun paska aksi M\&A terjadi penurunan yang relatif kecil yaitu hanya sebesar $7,27 \%$ di mana nilai rata rata sebelum merger $\&$ akuisisi yaitu 173,70 menjadi 161,07. Sementara nilai DER tertinggi terjadi tahun 2013 pada perusahaan PTPP yang mempunyai presentase 525,55\%. Semakin besar hasil rasio ini maka perusahaan harus menanggung resiko gagal bayar semakin besar.

Hasil penelitian ini tidak memberikan sinyal bagi pihak eksternal khususnya investor dan juga sinergi yang diharapkan oleh berbagai pihak tidak tercapai dalam kemampuan membiayai seluruh kewajiban perusahaan. Dengan demikian, kinerja keuangan rasio DER sebelum dan setelah M\&A ini tidak mendukung teori sinyal dan teori sinergi. Implikasi teori sinyal dan teori sinergi pada penelitian ini sebaiknya dalam meningkatkannya adalah hasil penjumlahan modal sendiri setelah perusahaan bergabung semakin lebih besar untuk mengurangi resiko gagal bayar atas seluruh utang.

Hasil didukung Mahesh \& Prasad (2012) pada perusahaan penerbangan di India tahun 2005 - 2010 diketahui bahwa kinerja keuangan dengan variabel DER setelah 2 tahun melakukan aksi M\&A tidak ada bedanya. Hasil ini tidak didukung Imelda \& Kristianti (2017) menyebutkan variabel DER ada bedanya 3 tahun paska M\&A pada industri semen 2009 - 2013.

\section{Perbedaan Kinerja Keuangan Diukur dengan Return on Equity (ROE) pada Perusahaan Akuisitor Sebelum dan Sesudah Merger \& Akuisisi (M\&A) \\ Berdasarkan hasil uji untuk ROE yaitu H3 diterima yaitu ada perbedaan kinerja keuangan diukur dengan Return on Equity (ROE) pada perusahaan akuisitor 3 tahun sebelum dan sesudah merger \& akuisisi. Perbedaan yang terjadi adalah sebuah penurunan di mana terlihat setelah 3 tahun paska merger \& akuisisi sedangkan 1 sampai 2 tahun paska M\&A masih belum terlihat. Berdasarkan tabel 1 bahwa selama 3 tahun rasio ini terus menurun karena aksi merger \& akuisisi tidak menjadikan kemampuan perusahaan akuisitor dalam menciptakan keuntungan semakin meningkat.}

Hal tersebut dibuktikan dengan nilai rata-rata ROE terjadi penurunan yang besar yaitu $118,92 \%$ di mana sebelum aktivitas merger \& akuisisi sebesar 121,05 dan setelahnya menjadi -22,90. Rasio ROE terendah dengan hasil negatif diperoleh perusahaan KBLV pada tahun 2018 sebesar -321,03\%. Semakin kecil presentase ROE mengindikasikan bahwa masih buruknya efesiensi penggunaan modal sendiri perusahaan yang berarti posisi pemilik perusahaan masih lemah. Hal ini menunjukkan bahwa hasil penggabungan dengan perusahaan lain dalam rangka memperbaiki profitabilitas tidak terwujud.

Manajemen perusahaan kurang mengoptimalkan penggunaan seluruh modal yang dimiliki dalam menaikan laba bersih perusahaan. Perubahan keuntungan akuisitor tidak signifikan paska M\&A artinya gagal mendapatkan laba ekonomis sehingga tidak mendukung teori sinergi. Selain itu, pihak calon investor mendapatkan sinyal kurang baik untuk pertimbangan berinvestasi sehingga hasil kinerja keuangan yang diukur dengan ROE mendukung teori sinyal namun dianggap sebagai bad news. Implikasi teori sinergi dan teori sinyal dalam penelitian ini untuk meningkatkan kinerja keuangan dengan ROE sebaiknya laba bersih yang dihasilkan perusahaan meningkat signifikan karena sudah terjadi pertambahan modal perusahaan setelah dilakukan M\&A. 
Unun Khoirun Nisak. Analisis Perbandingan Kinerja Keuangan Perusahaan Akuisitor Sebelum dan Sesudah Merger \& Akuisisi (M\&A) Tahun 2015

Konsistensi hasil ini sesuai oleh Eni,et al., (2016) yaitu secara signifikan ada beda proksi ROE 2 sampai 3 tahun setelah M\&A sektor manufaktur 2012. Hasil ini berlawanan oleh Reddy, et al., (2013) di mana tidak ada beda ROE paska merger pada sektor manufaktur \& jasa di India.

\section{Perbedaan Kinerja Keuangan Diukur dengan Total Assets Turnover (TATO) pada Perusahaan Akuisitor Sebelum dan Sesudah Merger \& Akuisisi (M\&A) \\ Bedasarkan hasil penelitian Total Assets Turnover (TATO) dijelaskan bahwa ada perbedaan kinerja keuangan diukur dengan Total Assets Turn Over (TATO) pada perusahaan akuisitor 3 tahun sebelum dan sesudah merger \& akuisisi, artinya H4 diterima. Perbedaan terlihat pada periode 3 tahun paska M\&A namun tidak terlihat periode 1 sampai 2 tahun paska M\&A. Perbedaan ini bukan menjadi meningkat akan tetapi sebaliknya yaitu sebuah penurunan karena perbandingannya antara total aset serta hasil penjualan diperoleh akuisitor paska M\&A tidak semakin besar.}

Dibuktikan pada tabel 1 bahwa periode 3 tahun paska M\&A nilai rata-rata TATO menurun sebesar 24,73\% yakni sebelum aktivitas M\&A sebesar 1,45 dan menjadi 1,09 sesudah M\&A. Perusahaan KBLV adalah salah satu perusahaan sampel yang memiliki rasio terendah yaitu setelah merger \& akuisisi pada tahun 2016 sebesar 0,10. Total penjualan yang dihasilkan lebih kecil senilai Rp1.308.250.000.000 dibandingkan total aset senilai Rp12.779.523.000.000. Semakin kecil rasio berarti total aktiva belum mampu memutar operasional perusahaan untuk mendapatkan laba optimal.

Data mengindikasikan bahwa ketidakmampuan perusahaan akuisitor memanfaatkan aset dengan optimal untuk meningkatkan hasil penjualan paska penggabungan usaha. Dengan demikian, perusahaan gagal dalam memperoleh sinergi untuk memaksimalkan pendapatan sehingga hasil penelitian ini diukur dengan TATO tidak mendukung teori sinergi. Hasil variabel ini juga pihak investor mendapat sinyal buruk untuk pertimbangan berinvestasi sehingga mendukung teori sinyal namun infomasi diterima sebagai bad news. Implikasi teori sinergi dan teori sinyal dalam penelitian ini seharusnya untuk meningkatkan kinerja keuangan rasio TATO yaitu hasil penjualan setelah penggabungan dengan perusahaan lain semakin meningkat akibat dari penggunaan aset perusahaan yang semakin optimal.

Penelitian ini didukung oleh Finansia (2017) menunjukkan proksi TATO ada beda setelah 2 tahun aksi M\&A di BEI periode 2010 - 2013. Penelitian juga sejalan dengan Rathih et al., (2018). Hasil tidak didukung Imelda \& Kristianti (2017) juga menunjukkan bahwa tidak adanya perbedaan pada variabel TATO selama 3 tahun setelah aksi akuisisi pada industri semen di Indonesia.

\section{Perbedaan Kinerja Keuangan Diukur dengan Market Value Added (MVA) pada Perusahaan Akuisitor Sebelum dan Sesudah Merger \& Akuisisi (M\&A)}

Variabel Market Value Added (MVA) disebutkan bahwa H5 diterima yaitu ada perbedaan kinerja keuangan diukur dengan Market Value Added (MVA) pada perusahaan akuisitor 3 tahun sebelum dan sesudah merger \& akuisisi. Pada 1 tahun dan 2 tahun hasil tidak menunjukkan perbedaan namun ketika periode 3 tahun hasil menunjukkan ada beda sebelum dan setelah M\&A. Perbedaan tersebut memberikan informasi terjadi penurunan yang berarti akuisitor tidak mampu untuk memaksimalkan nilai kekayaan bagi para pemegang sahamnya.

Dibuktikan pada tabel 1. Descriptive statistics bahwa nilai rata-rata MVA sebelum M\&A bernilai (+) akan tetapi paska M\&A bernilai (-). Penurunan terjadi sangat signifikan yaitu sebesar $208,97 \%$ di mana sebelum merger \& akuisisi nilai rata-rata sebesar 1,84E12 kemudian menurun menjadi 2,01E12. Hal ini disebabkan karena upaya merger \& akuisisi untuk menyatukan modal dari masingmasing perusahaan tidak menghasilkan perbandingan yang lebih besar setelah M\&A. Rendahnya nilai MVA ini mengindikasikan bahwa ekspektasi pasar yaitu para investor terhadap kemampuan manajemen perusahaan setelah merger $\&$ akuisisi mengalami penurunan.

Ekspektasi negatif dari investor ditunjukan dengan hasil yang diperoleh perusahaan DSSA pada tahun 2016. Di mana DSSA memiliki nilai pasar saham yang sangat rendah yaitu Rp4.276.565.376.000 dibandingkan seluruh modal yang diinvestasikan pemegang saham yaitu Rp17.242.797.829.560 
sehingga hasil MVA yang diperoleh bernilai negatif. Nilai negatif dapat dikatakan bahwa manajer gagal dalam meningkatkan kesejahteraan para pemegang saham perusahaan. Semakin kecil nilai MVA maka mencerminkan rendahnya kinerja perusahaan di masa mendatang karena harga saham dan jumlah saham beredar menjadi unsur utama dalam penilaian MVA. Meskipun tidak terlepas dari total modal yang telah disetorkan oleh investor. Kecilnya nilai MVA ini dapat diartikan bahwa manajer perusahaan kurang mampu mengoptimalkan seluruh modal yang telah diberikan investor.

Harapan untuk memakmurkan shareholder dan mengembangkan nilai bagi perusahaan tidak terwujud. Sehingga sinergi yang diinginkan untuk kinerja keuangan lebih baik tidak terealisasi yang artinya tidak mendukung teori sinergi. Begitu pula signaling theory di mana pihak calon investor menerima sinyal buruk untuk pertimbangan berinvestasi sehingga mendukung teori sinyal namun dianggap sebagai bad news. Implikasi teori sinergi dan teori sinyal dalam meningkatkan MVA sebaiknya adalah nilai harga saham setelah dilakukan M\&A menjadi semakin tinggi karena total modal yang disetor investor telah digunakan secara maksimal.

Hasil ini didukung Wardani \& Listiyadi (2018) yaitu secara signifikan ada beda nilai MVA 3 tahun paska M\&A listing di BEI 2010 - 2012. Begitupun juga Zulvina \& Musdholifah (2010) di mana variabel MVA terdapat perbedaan kinerja keuangan PT Unilever Indonesia sebelum dan setelah aktivitas M\&A. Hasil penelitian berlawanan Puspitasari (2014) ditemukan hasil MVA tidak terdapat perbedaan yang signifikan pada perusahaan sub sektor konstruksi bangunan tahun 2008 - 2009.

\section{KESIMPULAN}

Setiap variabel yang telah dianalisis maka disimpulkan tidak ada perbedaan kinerja keuangan diukur dengan Current Ratio (CR) dan Debt to Equity Ratio (DER) sedangkan Return on Equity (ROE), Total Asset Turn Over (TATO), dan Market Value Added (MVA) ada perbedaan pada perusahaan akuisitor 3 tahun sebelum dan sesudah merger \& akuisisi. Secara keseluruhan terjadi penurunan paska M\&A sehingga keinginan perusahaan untuk memperoleh sinergi kinerja keuangan yang lebih baik tidak tercapai. Implikasi hasil penelitian ini dengan perusahaan sampel supaya kinerja keuangan meningkat yaitu sebaiknya perusahaan mampu mengelola seluruh aset modal yang dimiliki agar terjadi peningkatan penjualan dan keuntungan serta aman dari resiko gagal bayar hutang. Sehingga tercipta nilai ekonomis dan kesejahteraan bagi semua pihak dalam perusahaan paska merger \& akuisisi. Selain itu, mengkaji ulang perusahaan target mengenai strategi merger dan akuisisi berdasarkan jenis kelompok dan memastikan pula bahwa perusahaan target merupakan perusahaan sehat agar nilai tambah dari kinerja keuangan dapat diperoleh setelah merger \& akuisisi.

Pemilihan sampel penelitian ini terbatas pada aktivitas perusahaan M\&A tahun 2015 saja. Tolok ukur kinerja keuangan yang digunakan hanya menggunakan 4 rasio keuangan dan 1 metode nilai pasar yaitu CR, DER, ROE, TATO, serta market value added. Selanjutnya, pendeknya waktu pengamatan yaitu 3 tahun sebelum dan setelah M\&A. Selain itu, perusahaan yang dalam penelitian ini juga melakukan corporate action lain selama periode penelitian.

Penelitian selanjutnya disarankan memperbanyak sampel perusahaan melalui perpanjangan tahun penelitian dan menambahkan variabel PLC dan memperpanjang periode pengamatan agar kinerja keuangan dan sinergi perusahaan yang dihasilkan dapat terlihat setelah aktivitas merger dan akuisisi. Bagi investor yang ingin menanamkan saham disarankan untuk lebih teliti dalam menganalisa kondisi perusahaan yang mempunyai riwayat merger \& akuisisi baik dari sisi kinerja keuangan maupun non kinerja keuangan sebagai tujuan investasi agar berjalan sesuai harapan.

\section{DAFTAR PUSTAKA}

Ahmed, M., \& Ahmed, Z. (2014). Mergers and Acquisitions : Effect on Financial Performance of Manufacturing Companies of Pakistan. Middle-East Journal of Scientific Research, 21(4), 689699. https://doi.org/10.5829/idosi.mejsr.2014.21.04.21442 
Unun Khoirun Nisak. Analisis Perbandingan Kinerja Keuangan Perusahaan Akuisitor Sebelum dan Sesudah Merger \& Akuisisi (M\&A) Tahun 2015

Bps.go.id. (2015). Badan Pusat Statistik: Merger dan Akuisisi. Retrieved October 10, 2019, from https://www.bps.go.id

Bradley, M., Desai, A., \& Kim, E. H. (1988). Synergistic Gains from Corporate Acquisitions and Their Division Between The Stockholders of Target and Acquiring Firms. Journal of Financial Economics, 21(1), 3-40. https://doi.org/10.1016/0304-405X(88)90030-X

Brigham, E. F., \& Houston, J. F. (2015). Dasar-dasar Manajemen Keuangan Buku 1 (Edisi 11). Jakarta: Salemba Empat.

Eni, N., Yusuf, A., \& Maryono. (2016). Perbandingan Kinerja Akuntansi Perusahaan Sebelum dan Sesudah Merger dan Akuisisi yang Terdaftar di Bursa Efek Indonesia. Jurnal Akuntansi (JA), $3(3), 50-61$.

Fahmi, I. (2012). Analisis Kinerja Keuangan. Bandung: Alvabeta.

Finansia, L. (2017). Analisis Kinerja Keuangan Perusahaan Sebelum dan Setelah Merger dan Akuisisi. Jurnal Bisnis Manajemen Indonesia (JMBI), 6(1), 43-54.

Gumanti, T. A. (2017). Keuangan Korporat: Tinjauan Teori dan Praktik Empiris. Jakarta: Mitra Wacana Media.

Hariyani, I., Serfianto, \& Yustisia, C. (2011). Merger,Konsolidasi, Akuisisi, \& Pemisahan Perusahaan: Cara Cerdas Mengembangkan dan Memajukan Perusahaan. Jakarta Selatan: Visimedia.

Hasanah, A. N., \& Oktaviani, T. M. (2017). Analisis Kinerja Perusahaan dan Abnormal Return Saham Sebelum dan Sesudah Akuisisi. Jurnal Akuntansi, 4(2), 75-88.

Horn, J. C. Van, \& Wachowicz, J. M. (2014). Prinsip-prinsip Manajemen Keuangan Buku 2 (Edisi 13). Jakarta: Salemba Empat.

idx.co.id. (2019). Bursa Efek Indonesia. Retrieved December 23, 2019, from www.idx.co.id

Imelda, \& Kristianti, R. A. (2017). Kinerja Akuisisi Industri Semen di Indonesia Tahun 2009-2013. DeReMa Jurnal Manajemen, 12(2), 269-284.

Kasmir. (2016). Analisis Laporan Keuangan. Jakarta: PT RajaGrafindo Persada.

Kompasiana.com. (2015, June 17). Tantangan Desa Menuju Masyarakat Ekonomi Asean (MEA) 2015. Retrieved October 2, 2019, from https://www.kompasiana.com

kppu.go.id. (2018). Komisi Pengawas Persaingan Usaha. Retrieved October 1, 2019, from https://www.kppu.go.id

Laiman, L., \& Hatane, S. E. (2017). Analisis Dampak Merger dan Akuisisi Terhadap Kinerja Keuangan pada Perusahaan Non Keuangan Yang Terdaftar di Bursa Efek Indonesia Periode Tahun 2007-2014. Journal Business Accounting Review, 5(2), 517-528.

Mahesh, R., \& Prasad, D. (2012). Post Merger and Acquisition Financial Perfomance Analysis : A Case Study of Select Indian Airline Companies. Internasional Journal of Engeneering and Management Sciences, 3(3), 362-369.

Marketeers.com. (2015, August 11). Ini Penyebab Merger dan Akuisisi di Indonesia Lesu. Retrieved October 5, 2019, from https://www.marketeers.com 
Moin, A. (2010). Merger Akuisisi \& Divestasi (Edisi 2). Yogyakarta: Ekonisia.

Puspitasari, R. (2014). Analisis Perbandingan Kinerja Keuangan Perusahaan Sub Sektor Properti \& Real Estate dan Sub Sektor Kontruksi Bangunan Menggunakan Metode Economic Value Added, Financial Value Added, dan Market Value Added (Studi pada Bursa Efek Indonesia Periode 2008-2013. E-Proceeding of Management, 1(13), 1-14.

Rathih, Y., Sari, K., \& Worokinasih, S. (2018). Analisis Perbandingan Kinerja Keuangan Sebelum dan Sesudah Merger dan Akuisisi ( Studi pada Perusahaan yang Terdaftar di Bursa Efek Indonesia yang Melakukan Merger dan Akuisisi pada Tahun 2013 ). Jurnal Administrasi Bisnis (JAB), 62(2), 166-175.

Reddy, K. S., Nangia, V. K., \& Agrawal, R. (2013). Corporate Mergers and Financial Performance : A New Assessment of Indian Cases. Journal Nankai Business Review International, 4(2), 107129. https://doi.org/10.1108/20408741311323326

Riyanto, B. (2001). Dasar-dasar Pembelanjaan Perusahaan (Edisi 4). Yogyakarta: BPFEYogyakarta.

Ross, S. A. (1977). The Determination of Financial Structure: The Incentive-Signalling Approach. The Bell Journal of Economics, 8(1), 23-40.

Sa'diyah, H., Hidayat, R. R., \& Husaini, A. (2015). Analisis Dampak Merger Terhadap Economic Value Added (EVA) dan Market Value Added (MVA) ( Studi Pada Perusahaan Di Bursa Efek Indonesia Yang Melakukan Merger Tahun 2011). Jurnal Administrasi Bisnis (JAB), 24(1), 1-9.

Sudana, I. M. (2011). Manajemen Keuangan Perusahaan Teori \& Praktik. Jakarta: Penerbit Erlangga.

Sugiyono. (2015). Metode Penelitian Pendidikan Pendekatan, Kuantitatif, Kualitatif, dan R\&D. Bandung: Alfabeta.

Tarigan, J., Claresta, A., \& Hatane, S. E. (2018). Analysis of Merger \& Acquisition Motives in Indonesian Listed Companies through Financial Performance Perspective. Jurnal Kinerja, 22(1), 95-112.

Tarigan, P. P. Y., \& Pratomo, W. A. (2015). Analisis Dampak Merger dan Akuisisi Terhadap Abnormal Return dan Kinerja Keuangan pada Perusahaan yang Terdaftar di Bursa Efek Indonesia. 3(3), 200-212.

Wardani, I. K., \& Listiyadi, A. (2018). Analisis Perbandingan Economic Value Added (EVA) dan Market Value Added (MVA) Pada Perusahaan Sebelum dan Sesudah Merger Maupun Akuisisi Periode 2010-2012 (Perusahaan Publik yang Terdaftar di Bursa Efek Indonesia). Jurnal Ilmu Manajemen, 6(1), 1-8.

Zen, N., Achsani, N. A., \& Andati, T. (2016). The Impact of Acquisition on Financial Performance of PT. ABC. Indonesian Journal of Business and Entrepreneurship, 2(3), 177-186. https://doi.org/10.17358/ijbe.2.3.177

Zulvina, R. A., \& Musdholifah. (2010). Analisis perbandingan Kinerja Keuangan Sebelum dan Sesudah Merger dengan Menggunakkan Metode Economic Value Added (EVA) dan Market Value Added (MVA) pada PT Unilever Indonesia Tbk. Jurnal Akuntansi Akrual, 1(2), 137157. https://doi.org/10.1017/CBO9781107415324.004 